\title{
Immunohistochemical expression and localization of somatostatin receptor subtypes in androgen ablated prostate cancer
}

\author{
Roberta Mazzucchelli a, ${ }^{\mathrm{a}}$, Doriana Morichetti ${ }^{\mathrm{a}, *}$, Alfredo Santinelli ${ }^{\mathrm{a}}$, Marina Scarpelli ${ }^{\mathrm{a}}$, Aldo V. Bono ${ }^{\mathrm{a}}$, \\ Antonio Lopez-Beltran ${ }^{\mathrm{b}}$, Liang Cheng ${ }^{\mathrm{c}}$ and Rodolfo Montironi ${ }^{\mathrm{a}, * *}$, \\ a Section of Pathological Anatomy, Polytechnic University of the Marche Region, School of Medicine, United \\ Hospitals, Ancona, Italy \\ ${ }^{\mathrm{b}}$ Department of Pathology, Reina Sofia University Hospital and Faculty of Medicine, Cordoba, Spain \\ ${ }^{\mathrm{c}}$ Department of Pathology and Laboratory Medicine, Indiana University School of Medicine, Indianapolis, IN, \\ USA
}

\begin{abstract}
Objective: The aim was to examine the expression and localization of the five somatostatin receptors (termed SSTR1-5) in radical prostatectomies (RPs) from patients with prostatic adenocarcinoma (PCa) under complete androgen ablation (CAA) before operation.

Material: The five SSTRs were evaluated in the epithelial, smooth muscle and endothelial cells of normal-looking epithelium (Nep), high-grade prostatic intraepithelial neoplasia (HGPIN) and PCa in 20 RPs with clinically detected PCa from patients under CAA. 20 RPs with clinically detected PCa from hormonally untreated patients were used as control group.

Results: Concerning the secretory cells (i) membrane staining was seen for SSTR3 and SSTR4; the mean percentages of positive cells, higher in SSTR3 than in SSTR4, decreased sharply in HGPIN and PCa compared with Nep; the mean percentages in the androgen ablated group were 30-90\% lower than in the untreated; (ii) cytoplasmic staining was seen for all 5 SSTRs; the mean percentages of positive cells in Nep, HGPIN and PCa of the untreated group were similar, and in general as high as $80 \%$ or more; in the treated group, the Nep values were similar to those in the untreated, whereas the values in HGPIN and PCa were lower for SSTR1, 3 and 5, with a decrease of 30\% for SSTR1; (iii) nuclear staining was seen with SSTR4 and SSTR5, the mean percentages for the former being much lower than for the latter; treatment affected both HGPIN and PCa, whose proportions of stained cells were 30-55\% lower than in the untreated group. Cytoplasmic staining in the basal cells was seen for all 5 SSTRs, both in Nep and HGPIN. The values in the treated group were lower than in the other, the difference between the two group being in general comprised between 10 and 40\%. Treatment did not affect SSTR staining in the smooth muscle and endothelial cells.

Conclusions: The present study expands our knowledge on the expression and localization of the five SSTRs in the prostate following CAA.
\end{abstract}

Keywords: Somatostatin receptors, prostate cancer, high-grade prostatic intraepithelial neoplasia, complete androgen ablation

\section{Introduction}

The effects of androgens in both the normal and neoplastic prostate are complemented by factors produced locally by stromal and epithelial cells, including the neuroendocrine (NE) cells. Among the pep-

\footnotetext{
These authors contributed equally to this work.

** Corresponding author: Rodolfo Montironi, MD, FRCPath, IFCAP, Section of Pathological Anatomy, Polytechnic University of the Marche Region, School of Medicine, United Hospitals, Via Conca 71, I-60126 Torrette, Ancona, Italy. E-mail: r.montironi@univpm.it.
}

tide hormones produced by these cells, somatostatin (SST) has gained the most attention due to its antiproliferative activity and to the clinical use of SST analogues [6].

The effects of SST analogues include a decreased tumour cell growth and angiogenesis as well as an increased cancer cell apoptosis [6]. These inhibitory effects are based on direct and indirect mechanisms. The former are mediated by tumours expressing SSTRs, whereas the latter may play a role in the regulation of SSTR-positive cells by modulating the effect of their growth stimuli, including the inhibition of secre- 
tion of growth-promoting factors, such as insulin-like growth factor-1, epidermal growth factor and transforming growth factor, all of which specifically regulate tumour growth [6].

Previous studies from our group evaluated the expression and localization of the five SSTRs in conventional PCa and in PCa with NE differentiation $[15,16]$. The investigations pointed out that typing somatostatin receptor expression could be of great relevance in somatostatin analogue-based diagnostic and treatment approaches. No information is available in the current literature on whether CAA affects SSTR subtype expression and localization in $\mathrm{PCa}$. This information would be of paramount importance in therapeutic approaches in which SST analogues could be combined with other drugs, including those that interfere with the effect of androgens on PCa.

The aim of the study was to examine the expression and localization of the somatostatin receptors (SSTRs) in radical prostatectomy specimens with clinical prostate cancer $(\mathrm{PCa})$ from patients under CAA before operation.

\section{Material and methods}

Forty RPs were obtained from the Pathology Services associated with the United Hospitals-Polytechnic University of the Marche Region. The specimens represented two groups of patients whose characteristics are in Table 1:

- Group 1: twenty RPs with untreated acinar PCa (see below). HGPIN was present in all 20. These cases were from men with clinically detected PCa. None of them was under androgen manipulation before surgery. This group, used as control, was included in a previous investigation [16].
- Group 2: twenty RPs with treated acinar PCa (see below). HGPIN was present in all 20. These cases were from men with clinically detected $\mathrm{PCa}$ and under CAA (a LHRH analogue plus a nonsteroidal antiandrogen) for three months before surgery. None of the cases of this group showed neuroendocrine differentiation other than a few scattered Chromogranin A positive cells.

Complete sampling was used to process the surgical specimens, examined histologically as $5 \mu \mathrm{m}$ thick whole-mount haematoxylin and eosin stained sections [14]. The most representative blocks of the peripheral zone containing Nep, HGPIN and PCa were selected for immunohistochemistry. The PCa of these two groups was pT2a and Gleason score $6(3+3)$ (see also below), thus avoiding the influence of tumour stage and grade in the expression of the five SSTRs.

The Gleason score of Group 2 refers to the evaluation made in the pre-therapy biopsy. The reason for not using the Gleason score in the CAA specimens was that the therapy induced regressive changes to the point that the tumour architecture, upon which the Gleason grading system is based, was no longer identifiable. We are aware of the fact that there is some discrepancy between the Gleason score of the biopsy and that of the specimen. In our experience $20 \%$ of patients with a Gleason score $3+3=6$ in their biopsies have a higher score in the specimens, usually 7 , the pattern 4 being in general of limited extent (unpublished observations). This means that, while the untreated RPs used in this study had all a Gleason score $3+3=6$, the other group could have had a small proportion of cases with a higher score. However, the tumour present in our 20 cases from CAA patients showed all evident regressive changes, as it is usually seen in tumours with a Gleason score of 6 or lower.

Concerning recognition of HGPIN following CAA a certain degree of secretory cell type stratification was

Table 1

Patient characteristics

\begin{tabular}{|c|c|c|c|c|c|}
\hline Group & No. of patients & Mean age (years) and range & Total serum PSA $(\mathrm{ng} / \mathrm{ml})$ & Type of specimens & Cancer features* \\
\hline Untreated & 20 & $66(44-74)$ & $2.4(0.4-3.9)$ & $\mathrm{RP}$ & $\begin{array}{c}\text { pT2a, GS } 6(3+3), \text { PZ, } \\
\text { TTV, cc: } 1.21(0.40-3.51)\end{array}$ \\
\hline $\begin{array}{l}\text { Androgen } \\
\text { ablated }\end{array}$ & 20 & $63(43-73)$ & $2.9 * *(0.5-4.4)$ & $\mathrm{RP}$ & $\begin{array}{l}\text { pT2a, GS } 6(3+3)^{* *}, \text { PZ, } \\
\text { TTV, cc: } 0.19(0.02-1.23)\end{array}$ \\
\hline
\end{tabular}

Notes: See text for abbreviations.

* Pathologic stage according to the 2009 TNM revision (all the patients were $\mathrm{N} 0$ and there was no evidence of metastasis related to prostate neoplasia); GS - Gleason score; PZ - cancer origin in the peripheral zone; TTV - total tumour volume; cc - cubic centimeters; median and range. ${ }^{* *}$ PSA and GS as determined at the time of (PSA) and in the initial prostate biopsy (GS). 
always present. However, crowding was less evident than in the untreated high-grade PIN. The cells showed cytoplasmic clearing and enlargement by coalescence of vacuoles and rupture of cell membranes. The nuclei had different degrees of chromatin changes which range from a mild condensation to a tightly condensed state close to that observed in apoptosis. The nucleoli became inconspicuous, without margination, and had a decreased diameter. The basal-cell layer was easily recognisable in most instances.

The immunohistochemical evaluation was also done in consecutive sections from 5 pre-treatment biopsies with Nep and $\mathrm{PCa}$, representing 5 out the 20 patients of Group 2.

The procedure for this research project conforms to the provisions of the Declaration of Helsinki.

\subsection{Immunohistochemical staining}

\subsubsection{Antibody against somatostatin receptor subtypes}

For immunohistochemistry, all rabbit polyclonal anti-SSTR subtype antibodies were commercially obtained from Chemicon ${ }^{\circledR}$ International Inc. (Temecula, CA, USA). Dilution of the antibodies used is shown in Table 2. Positive control experiments included normal human pancreas and/or anterior pituitary gland obtained from surgery and autopsy, respectively. Negative controls were used for the tested antibodies; the primary antibody was replaced by rabbit non-immune serum.

\subsubsection{Immunohistochemistry}

Serial $5 \mu \mathrm{m}$ thick sections mounted on silane-coated slides were dewaxed in xylene and rehydrated through a graded series of ethanol. Antigen retrieval was done by microwave treatment for $20 \mathrm{~min}$ at $98^{\circ} \mathrm{C}$ using 0.01 M Citric Acid buffer pH 6.0. Endogenous peroxi- dase activity was quenched by incubating the sections in $3 \%$ hydrogen peroxide for $10 \mathrm{~min}$ at room temperature. Non-specific binding sites were blocked through pre-incubation with $1 \%$ albumin bovine in PBS for $20 \mathrm{~min}$ at room temperature. Reacted tissue sections were then incubated with the antibodies for each SSTR subtype for $18 \mathrm{~h}$ at $4^{\circ} \mathrm{C}$. Antigen-antibody complex was subsequently visualized using the Envision ${ }^{\mathrm{TM}} \mathrm{De}$ tection System kit peroxidase/DAB (DAKO, Glustrop, Denmark) and counterstained with haematoxylin.

\subsubsection{Evaluation of immunohistochemistry and statistics}

At least 1,000 cells were counted by one of us (DM) in contiguous $400 \times$ microscopic fields in each case, for the epithelial cells, separately in Nep, HGPIN and $\mathrm{PCa}$, as well as for the smooth muscle cells of the stroma and endothelial cells. The basal cells were evaluated in Nep and HGPIN. Nep was at least $5 \mathrm{~mm}$ away from $\mathrm{PCa}$, whereas smooth muscle and endothelial cells were measured in areas approximately $1 \mathrm{~mm}$ away from PCa. Immunostaining was evaluated for the following three cell components: cytoplasm, membrane and nucleus. Staining intensity was subjectively graded as $1+, 2+$ and $3+$. In each case the percentages of positive cells and of cells with strong intensity (i.e., $2+$ and $3+$ ) were evaluated. For each group the mean and standard deviation were then calculated. The differences between groups were considered statistically significant at a value of $p<0.05$ (Mann-Whitney test, SPSS software, SPSS Inc., Chicago, IL, USA).

\subsection{Assessment of antibody specificity}

The specificity of the five rabbit polyclonal antiSSTR antibodies employed in this study was shown

Table 2

Characteristics of the polyclonal antibodies used in immunohistochemistry

\begin{tabular}{lclcc}
\hline Antibody & Type & Immunogen* i.e., synthetic peptide from: & Dilution & Source \\
\hline SSTR1 & Rabbit & C-terminal domain of human SSTR1 & $1 / 300$ & Chemicon International Inc., USA \\
SSTR2 & Rabbit & 2nd extracellular domain of human SSTR2 & $1 / 100$ & Chemicon International Inc., USA \\
SSTR3 & Rabbit & C-terminal domain of human SSTR3 & $1 / 300$ & Chemicon International Inc., USA \\
SSTR4 & Rabbit & N-terminal extracellular domain & $1 / 400$ & Chemicon International Inc., USA \\
& & of human SSTR4 & $1 / 200$ & Chemicon International Inc., USA \\
SSTR5 & Rabbit & C-terminal domain of human SSTR5 & Ready-to-use & Dako, Denmark \\
"Visualization System" & ENVISIONTM & - &
\end{tabular}

Note: *From Manufacturer's data sheet. 
in a previous investigation with a western blot technique [13].

\section{Results}

The data for the 5 SSTRs in the epithelial, smooth muscle and endothelial cells in Nep, HGPIN and PCa are reported in Tables 3-7. Examples of the SSTR immunostaining in untreated and treated Nep, HGPIN and PCa are shown in Fig. 1A-F.

\subsection{Epithelial secretory cells}

Membrane staining was seen for SSTR3 and SSTR4 (Table 3). The mean percentages of positive cells, higher in SSTR3 than in SSTR4, decreased sharply in HGPIN and PCa compared with Nep, in both groups. The mean percentages in the androgen ablated group were 30-90\% lower than in the untreated one (Nep, SSTR3: $p<0.001$; HGPIN, SSTR4: $p=0.006$ ). A small proportion of cells with strong intensity was only seen in the untreated Nep cases and, to much lower extent, in the treated Nep ones.
Cytoplasmic staining was seen for all 5 SSTRs (Table 4). The mean percentages of positive cells in Nep, HGPIN and PCa of the untreated group were similar, and in general as high as $80 \%$ or more. In the treated group, the Nep values were similar to those in the untreated, whereas the values in HGPIN and PCa were lower for SSTR1, 3 and 5, with a decrease of $30 \%$ for SSTR1 (HGPIN, SSTR1: $p=0.022$; PCa, SSTR1: $p<0.001$ ). As shown in Table 4 (values in parenthesis), treatment reduced the percentages of strongly stained cells for all 5 SSTRs in Nep, HGPIN and PCa.

Nuclear staining was seen with SSTR4 and SSTR5 (Table 5). The mean percentages for the former being much lower than for the latter. Treatment affected both HGPIN and PCa, whose proportions of stained cells were 30-55\% lower than in the untreated group (PCa, SSTR4: $p=0.024$; HGPIN, SSTR5: $p=0.002$ ). SSTR expression in Nep was no affected.

\subsection{Basal cells}

Cytoplasmic staining was seen for all 5 SSTRs, both in Nep and HGPIN (Table 6). The values in the treated

Table 3

Percentages (mean \pm standard deviation) of secretory cells with positive cell membrane staining

\begin{tabular}{|c|c|c|c|c|c|c|}
\hline \multirow[t]{2}{*}{ SSTRs } & \multicolumn{2}{|c|}{ Normal-looking epithelium } & \multicolumn{2}{|c|}{ HGPIN } & \multicolumn{2}{|c|}{$\mathrm{PCa}$} \\
\hline & Untreated & Androgen ablated & Untreated & Androgen ablated & Untreated & Androgen ablated \\
\hline \multirow[t]{2}{*}{ Subtype 3} & $54.1 \% \pm 22.5$ & $38.6 \% \pm 6.6$ & $5.4 \% \pm 9.7$ & $1.6 \% \pm 1.5$ & $6.3 \% \pm 9.3$ & $2.3 \% \pm 1.1$ \\
\hline & $(13.8 \% \pm 8.6)$ & $(1.3 \% \pm 1.3)$ & $(0 \% \pm 0)$ & $(0 \% \pm 0)$ & $(0.2 \% \pm 0.4)$ & $(0 \% \pm 0)$ \\
\hline \multirow[t]{2}{*}{ Subtype 4} & $9.2 \% \pm 11.3$ & $5.2 \% \pm 6.1$ & $4.2 \% \pm 4.1$ & $0.4 \% \pm 0.6$ & $5.8 \% \pm 3.5$ & $0.6 \% \pm 0.8$ \\
\hline & $(0.2 \% \pm 0.4)$ & $(0 \% \pm 0)$ & $(0 \% \pm 0)$ & $(0 \% \pm 0)$ & $(0 \% \pm 0)$ & $(0 \% \pm 0)$ \\
\hline
\end{tabular}

Note: The values in brackets are those with strong intensity, i.e., with $2+$ and $3+$.

Table 4

Percentages (mean \pm standard deviation) of secretory cells with positive cytoplasmic staining

\begin{tabular}{|c|c|c|c|c|c|c|}
\hline \multirow[t]{2}{*}{ SSTRs } & \multicolumn{2}{|c|}{ Normal-looking epithelium } & \multicolumn{2}{|c|}{ HGPIN } & \multicolumn{2}{|c|}{$\mathrm{PCa}$} \\
\hline & Untreated & Androgen ablated & Untreated & Androgen ablated & Untreated & Androgen ablated \\
\hline Subtype 1 & $\begin{array}{r}80.3 \% \pm 10.3 \\
(6.4 \% \pm 4.9)\end{array}$ & $\begin{array}{r}80 \% \pm 6.64 \\
(4.9 \% \pm 3.1)\end{array}$ & $\begin{array}{l}80.3 \% \pm 11.5 \\
(8.3 \% \pm 6.7)\end{array}$ & $\begin{array}{c}54.7 \% \pm 26.8 \\
(3.9 \% \pm 2.1)\end{array}$ & $\begin{array}{c}80.5 \% \pm 14.8 \\
(8.7 \% \pm 7.2)\end{array}$ & $\begin{array}{l}53.8 \% \pm 20.4 \\
(2.5 \% \pm 2.0)\end{array}$ \\
\hline Subtype 2 & $\begin{array}{r}81.2 \% \pm 14.5 \\
(6.0 \% \pm 4.0)\end{array}$ & $\begin{array}{l}79.5 \% \pm 6.9 \\
(5.0 \% \pm 3.1)\end{array}$ & $\begin{array}{l}81.9 \% \pm 11.8 \\
(8.0 \% \pm 5.7)\end{array}$ & $\begin{array}{c}75.1 \% \pm 16.7 \\
(5.0 \% \pm 4.1)\end{array}$ & $\begin{array}{c}83.8 \% \pm 9.2 \\
(10.2 \% \pm 4.7)\end{array}$ & $\begin{array}{r}74.2 \% \pm 13.5 \\
\quad(5.3 \pm 3.4)\end{array}$ \\
\hline Subtype 3 & $\begin{array}{l}81.9 \% \pm 10.2 \\
(8.1 \% \pm 6.1)\end{array}$ & $\begin{array}{l}81.6 \% \pm 4.88 \\
(4.0 \% \pm 2.1)\end{array}$ & $\begin{array}{l}82.5 \% \pm 11.2 \\
(9.5 \% \pm 5.1)\end{array}$ & $\begin{array}{r}73 \% \pm 18.2 \\
(3.5 \% \pm 1.9)\end{array}$ & $\begin{array}{c}83.2 \% \pm 14.9 \\
(10.5 \% \pm 7.4)\end{array}$ & $\begin{array}{l}72.2 \% \pm 8.4 \\
(4.5 \% \pm 2.9)\end{array}$ \\
\hline Subtype 4 & $\begin{array}{l}84.3 \% \pm 9.7 \\
(5.1 \% \pm 2.9)\end{array}$ & $\begin{array}{l}85.6 \% \pm 7.3 \\
(4.0 \% \pm 3.6)\end{array}$ & $\begin{array}{l}84.9 \% \pm 8.9 \\
(9.2 \% \pm 3.3)\end{array}$ & $\begin{array}{l}84.4 \% \pm 5.3 \\
(5.1 \% \pm 4.3)\end{array}$ & $\begin{array}{c}86.7 \% \pm 9.9 \\
(13.9 \% \pm 13.8)\end{array}$ & $\begin{array}{l}83.3 \% \pm 9.2 \\
(4.8 \% \pm 4.9)\end{array}$ \\
\hline Subtype 5 & $\begin{array}{l}78.2 \% \pm 8.2 \\
(4.7 \% \pm 2.6)\end{array}$ & $\begin{array}{l}80.3 \% \pm 7.2 \\
(4.5 \% \pm 3.9)\end{array}$ & $\begin{array}{l}79.0 \% \pm 18.9 \\
(5.8 \% \pm 3.3)\end{array}$ & $\begin{array}{c}68.8 \% \pm 17.6 \\
(3.3 \% \pm 1.7)\end{array}$ & $\begin{array}{c}80.7 \% \pm 13.1 \\
(6.1 \% \pm 6.5)\end{array}$ & $\begin{array}{c}66.2 \% \pm 19.2 \\
(3.3 \% \pm 2.0)\end{array}$ \\
\hline
\end{tabular}

Note: The values in brackets are those with strong intensity, i.e., with $2+$ and $3+$. 
Table 5

Percentages (mean \pm standard deviation) of secretory cells with positive nuclear staining

\begin{tabular}{|c|c|c|c|c|c|c|}
\hline \multirow[t]{2}{*}{ SSTRs } & \multicolumn{2}{|c|}{ Normal-looking epithelium } & \multicolumn{2}{|c|}{ HGPIN } & \multicolumn{2}{|c|}{$\mathrm{PCa}$} \\
\hline & Untreated & Androgen ablated & Untreated & Androgen ablated & Untreated & Androgen ablated \\
\hline Subtype 4 & $\begin{array}{c}20.2 \% \pm 8.8 \\
(0 \% \pm 0)\end{array}$ & $\begin{array}{c}20.1 \% \pm 8.0 \\
(0 \% \pm 0)\end{array}$ & $\begin{array}{c}22.9 \% \pm 15.4 \\
(0 \% \pm 0)\end{array}$ & $\begin{array}{c}15.4 \% \pm 13.7 \\
(0 \% \pm 0)\end{array}$ & $\begin{array}{c}26.8 \% \pm 15.3 \\
(0 \% \pm 0)\end{array}$ & $\begin{array}{c}14.05 \% \pm 8.6 \\
(0 \% \pm 0)\end{array}$ \\
\hline Subtype 5 & $\begin{array}{c}45.4 \% \pm 7.4 \\
(0 \% \pm 0)\end{array}$ & $\begin{array}{l}43 \% \pm 18.4 \\
(0 \% \pm 0)\end{array}$ & $\begin{array}{c}31.4 \% \pm 14.4 \\
(0 \% \pm 0)\end{array}$ & $\begin{array}{c}14.1 \% \pm 7.9 \\
(0 \% \pm 0)\end{array}$ & $\begin{array}{c}33.7 \% \pm 25.1 \\
(0 \% \pm 0)\end{array}$ & $\begin{array}{c}15.2 \% \pm 13.3 \\
(0 \% \pm 0)\end{array}$ \\
\hline
\end{tabular}

Note: The values in brackets are those with strong intensity, i.e., with $2+$ and $3+$.

Table 6

Percentages (mean \pm standard deviation) of basal cells with positive cytoplasmic staining

\begin{tabular}{|c|c|c|c|c|}
\hline \multirow[t]{2}{*}{ SSTRs } & \multicolumn{2}{|c|}{ Normal-looking epithelium } & \multicolumn{2}{|c|}{ HGPIN } \\
\hline & Untreated & Androgen ablated & Untreated & Androgen ablated \\
\hline \multirow[t]{2}{*}{ Subtype 1} & $84.1 \% \pm 12.1$ & $71.2 \% \pm 5.8$ & $59.6 \% \pm 9.6$ & $41.9 \% \pm 9.4$ \\
\hline & $(26.2 \% \pm 19.3)$ & $(11 \% \pm 5.4)$ & $(3.4 \% \pm 3.2)$ & $(2.1 \pm 3.3)$ \\
\hline \multirow[t]{2}{*}{ Subtype 2} & $47.8 \% \pm 31.3$ & $41.3 \% \pm 19.3$ & $45.4 \% \pm 34.3$ & $28.7 \% \pm 9.5$ \\
\hline & $(1.3 \% \pm 2.1)$ & $(1.5 \% \pm 1.7)$ & $(6.9 \% \pm 6.7)$ & $(0.7 \% \pm 1)$ \\
\hline \multirow[t]{2}{*}{ Subtype 3} & $85.8 \% \pm 12.5$ & $73.2 \% \pm 12.2$ & $66.3 \% \pm 14.5$ & $63.5 \% \pm 18.1$ \\
\hline & $(30.6 \% \pm 25.9)$ & $(25.7 \% \pm 4.3)$ & $(22.6 \% \pm 5.7)$ & $(14.1 \% \pm 7.8)$ \\
\hline \multirow[t]{2}{*}{ Subtype 4} & $68.0 \% \pm 20.3$ & $53.9 \% \pm 12.7$ & $28.4 \% \pm 7.8$ & $24.3 \% \pm 11.3$ \\
\hline & $(13.2 \% \pm 11.8)$ & $(11.7 \% \pm 4.2)$ & $(0 \% \pm 0)$ & $(0 \% \pm 0)$ \\
\hline \multirow[t]{2}{*}{ Subtype 5} & $45.0 \% \pm 20.6$ & $41.0 \% \pm 19$ & $29.3 \% \pm 21.7$ & $23.8 \% \pm 7.4$ \\
\hline & $(12.7 \% \pm 3.1)$ & $(2.4 \% \pm 2.3)$ & $(0 \% \pm 0)$ & $(0 \% \pm 0)$ \\
\hline
\end{tabular}

Note: The values in brackets are those with strong intensity, i.e., with $2+$ and $3+$.

Table 7

Percentages (mean \pm standard deviation) of smooth muscle and endothelial cells with positive cytoplasmic staining

\begin{tabular}{|c|c|c|c|c|}
\hline \multirow[t]{2}{*}{ SSTRs } & \multicolumn{2}{|c|}{ Smooth muscle cells } & \multicolumn{2}{|c|}{ Endothelial cells } \\
\hline & Untreated & Androgen ablated & Untreated & Androgen ablated \\
\hline \multirow[t]{2}{*}{ Subtype 1} & $91.7 \% \pm 8.5$ & $82.8 \% \pm 13.9$ & $99.6 \% \pm 1.2$ & $99.5 \% \pm 2.2$ \\
\hline & $(57.5 \% \pm 35.5)$ & $(50.7 \% \pm 17.3)$ & $(58.3 \% \pm 2.4)$ & $(92.9 \% \pm 7.2)$ \\
\hline \multirow[t]{2}{*}{ Subtype 2} & $56.0 \% \pm 20.0$ & $55.5 \% \pm 18.1$ & $30.2 \% \pm 10.1$ & $30.1 \% \pm 7.9$ \\
\hline & $(7.0 \% \pm 3.9)$ & $(3.9 \% \pm 3.6)$ & $(7.8 \% \pm 4.0)$ & $(6.2 \% \pm 4.3)$ \\
\hline \multirow[t]{2}{*}{ Subtype 3} & $67.0 \% \pm 19.3$ & $64.6 \% \pm 10.9$ & $59.0 \% \pm 17.8$ & $52.1 \% \pm 15.4$ \\
\hline & $(5.2 \% \pm 4.1)$ & $(6.7 \% \pm 4.4)$ & $(6.9 \% \pm 4.8)$ & $(6.2 \% \pm 4.5)$ \\
\hline \multirow[t]{2}{*}{ Subtype 4} & $56.9 \% \pm 23.2$ & $55.6 \% \pm 9$ & $61.3 \% \pm 13.9$ & $52.9 \% \pm 10.9$ \\
\hline & $(3.4 \% \pm 2.1)$ & $(3.2 \% \pm 3.5)$ & $(4.8 \% \pm 1.5)$ & $(3.5 \% \pm 3.2)$ \\
\hline \multirow[t]{2}{*}{ Subtype 5} & $22.3 \% \pm 15.6$ & $22.8 \% \pm 13.9$ & $21.3 \% \pm 16.2$ & $19.8 \% \pm 10.1$ \\
\hline & $(0.8 \% \pm 0.6)$ & $(5.7 \% \pm 0.3)$ & $(0.3 \% \pm 0.7)$ & $(0.1 \% \pm 0.5)$ \\
\hline
\end{tabular}

Note: The values in brackets are those with strong intensity, i.e., with $2+$ and $3+$.

group were lower than in the other, the difference between the two group being in general comprised between 10 and 40\% (Nep, SSTR1: $p=0.001$; HGPIN, SSTR1: $p<0.001$; Nep, SSTR3: $p=0.005$; Nep, SSTR4: $p=0.044)$.

\subsection{Smooth muscle and endothelial cells}

The pattern of cytoplasmic staining in the smooth muscle and endothelial cells was similar (Table 7). Treatment did not affect SSTR staining. The highest 


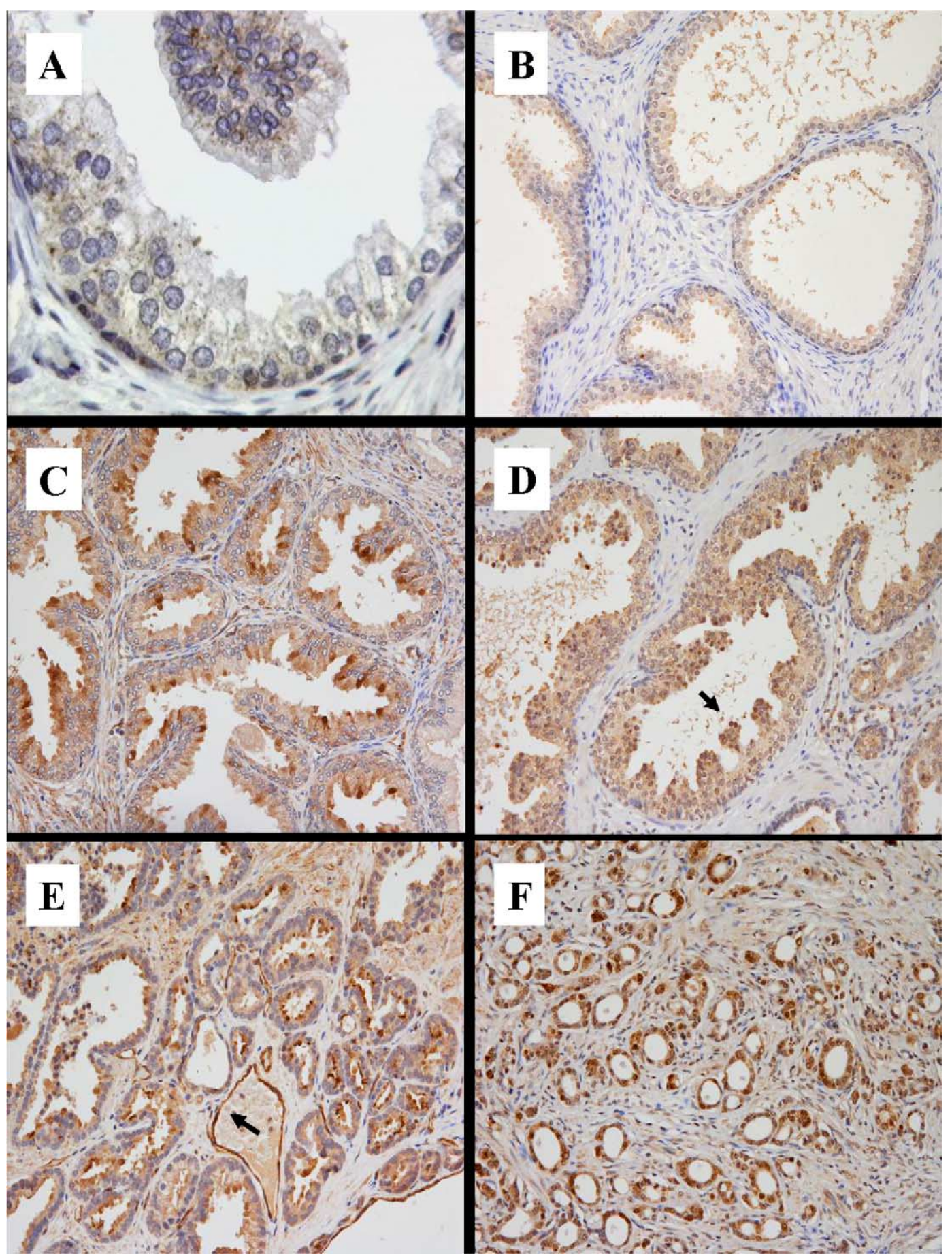

Fig. 1. Immunostaining for the SSTR subtype 4. Faint staining (1+) in the cytoplasm of the basal and to a less extent in the secretory cells in the untreated (A) and androgen ablated normal looking epithelium (B). Moderate (2+) to strong (3+) staining in the cytoplasm and to a less extent in the membrane of untreated (C) and androgen ablated (D) HGPIN. Stromal and endothelial staining is seen in C whereas nuclear staining in the secretory cells is seen in D (arrow). Moderate (2+) to strong (3+) staining in the cytoplasm and to a less extent in the membrane of untreated (E) and androgen ablated (F) PCa. Strong endothelial staining is seen in E (arrow). 
mean values were seen for SSTR1 and the lowest for SSTR5. There were no cases with a distinct positivity in the cell membrane. Nuclear staining, seen only with the subtypes 4 and 5, was always weak and in a scattered cells.

The results obtained in the five pre-treatment biopsies with Nep and PCa were comparable to those seen in the untreated Group 1 (data not shown). Chromogranin A immunohistochemistry was done in deeper sections in two biopsies with $3+$ cytoplasmic staining for the SSTR2 and 4 in the epithelium. Some but not all of the cells present in the same location were also Chromogranin A positive.

\section{Discussion}

Somatostatin (SST) is a 14- or 28-amino acid peptide that was originally described in 1973 as a hypothalamic NE hormone [3], whose role was to inhibit the secretion of growth hormone from the anterior pituitary gland. The presence of this peptide hormone was subsequently detected throughout the central and peripheral nervous systems, and in several organs, including the prostate.

The actions of SST are mediated by a family of transmembrane domain G-protein-coupled receptors that comprise five distinct subtypes and that share common signaling pathways [17]. Although SSTRs are membrane-associated receptors, a significant amount of staining is seen within the cytoplasm, and some nuclear staining is also present in many immunoreactive cells [13]. The interpretation, based also on molecular studies by others $[9,10,19]$, is that, after binding their ligand at the cell membrane level, SSTR-ligand complexes undergo cellular internalization with progressive translocation from the cytoplasm to the nucleus where SSTRs exert the effect of somatostatin.

SSTRs are widely expressed in many organs $[1,5,11$, $18,21,24]$, including the prostate $[8,20]$, in the normal tissue as well as in benign and malignant lesions, at the level of epithelial, stromal smooth muscle and endothelial cells. Frequently multiple subtypes coexist in the same cell. The SSTRs present in the epithelial cells mediate the antiproliferative effect of SST. A possible role of the SSTRs in the smooth muscle could be to influence the release of various growth factors known to be synthesized in the stroma. As several of these growth factors act in a paracrine manner on the glandular part of the prostate to regulate prostate growth
[6], somatostatin could indirectly regulate biological events in the prostatic gland through a stromal action. Precise role of the SSTRs in endothelial cells have not yet been clarified, but somatostatin may be involved in angiogenesis.

Cloning of five SSTRs has led to the development of subtype-selective agonists. The antiproliferative and antiangiogenic properties of SSTR2-specific SST analogues octreotide and lanreotide have been exploited in several clinical trials $[2,22]$. Therefore, it is very important to determine cell expression and localization of the five SSTRs. SSTR profiling in individual patients may be of relevance to better tailor the somatostatin analogue-based diagnosis and treatment.

Detailed information on the expression and localization of the five SSTR subtypes in epithelial cells in normal prostate, HGPIN and PCa, including cancers with NE differentiation, as well as in the smooth muscle and endothelial cells from hormonally untreated prostates has been reported in a number of studies $[3,4,6-8,15$, 16,20,23] (Table 8).

The current investigation shows that the five SSTRs are detectable in prostate tissue from patients under CAA, even though there is reduction of their level in the epithelial cells, mostly in HGPIN and PCa (Table 9). Their expression and localization are unchanged in the smooth muscle and endothelial cells. This is the first study that documents such a pattern of SSTR expression and localization in the prostate lesions following androgen ablation. To the best of our knowledge there is only one previous study with some similarities with our current investigation, in which the effect of chemotherapy on SSTR expression was evaluated. It was found that chemotherapy seemed to reduce the cellular receptors for SST analogues [12].

The limitation of our study is that immunohistochemistry was not associated with a molecular investigation. This type of comparative study was done to some extent by others, including Hansson et al. [8] in human benign prostatic hyperplasia and prostatic cancer, and Klisovic et al. [10] in human ocular tissue. The former group investigated SSTR2 and SSTR4 only. The latter investigated SSTR1 and SSTR2 in particular. Both groups found good correlation between immunohistochemical distribution of SSTRs and their gene expression.

In conclusion, the present study greatly expands our knowledge on the expression and localization of the five SSTRs in the epithelial, stromal smooth muscle and blood vessel endothelial cells by investigating 
Table 8

Studies on the expression and localization of the SSTRs in human prostate tissue

\begin{tabular}{|c|c|c|c|c|c|}
\hline Authors and reference & Year & Techniques & Receptors & Localization & Type of tissue \\
\hline Reubi et al. [20] & 1995 & $\begin{array}{l}\text { Autoradiography, } \\
\text { in situ hybridization }\end{array}$ & $\begin{array}{l}\text { SSTR1 } \\
\text { SSTR2 } \\
\text { SSTR3 }\end{array}$ & Smooth muscle, endothelium & $\begin{array}{l}\text { Benign prostatic hyperplasia } \\
\text { and prostate cancer }\end{array}$ \\
\hline Halmos et al. [7] & 2000 & RT-PCR & $\begin{array}{l}\text { SSTR1 } \\
\text { SSTR2 } \\
\text { SSTR5 }\end{array}$ & Epithelial cells & Prostate cancer \\
\hline Dizeyi et al. [6] & 2002 & $\begin{array}{l}\text { IHC, RT-PCR, } \\
\text { Western blot }\end{array}$ & $\begin{array}{l}\text { SSTR1 } \\
\text { SSTR2 } \\
\text { SSTR3 } \\
\text { SSTR4 } \\
\text { SSTR5 }\end{array}$ & $\begin{array}{l}\text { Epithelial cells, } \\
\text { stromal cells, endothelium }\end{array}$ & $\begin{array}{l}\text { Normal, benign prostatic hyperplasia, } \\
\text { prostate cancer }\end{array}$ \\
\hline Hansson et al. [8] & 2002 & In situ hybridization & $\begin{array}{l}\text { SSTR2 } \\
\text { SSTR4 }\end{array}$ & Epithelial cells, stromal cells & $\begin{array}{l}\text { Benign prostatic hyperplasia PIN, } \\
\text { prostate cancer }\end{array}$ \\
\hline Volante et al. [23] & 2007 & IHC & $\begin{array}{l}\text { SSTR2A } \\
\text { SSTR3 } \\
\text { SSTR5 }\end{array}$ & Epithelial cells & Cancer \\
\hline Montironi et al. [13] & 2008 & $\mathrm{IHC}$ & $\begin{array}{l}\text { SSTR1 } \\
\text { SSTR2 } \\
\text { SSTR3 } \\
\text { SSTR4 } \\
\text { SSTR5 }\end{array}$ & $\begin{array}{l}\text { Secretory cells, basal cells, } \\
\text { smooth muscle stromal cells, } \\
\text { endothelial cells }\end{array}$ & Benign prostatic hyperplasia \\
\hline Cariaga-Martinez et al. [4] & 2009 & $\mathrm{IHC}$ & SSTR2 & $\begin{array}{l}\text { Luminal side of duct } \\
\text { and acinar cells }\end{array}$ & $\begin{array}{l}\text { Normal, benign hyperplasia } \\
\text { and prostate cancer }\end{array}$ \\
\hline Morichetti et al. [16] & 2009 & IHC & $\begin{array}{l}\text { SSTR1 } \\
\text { SSTR2 } \\
\text { SSTR3 } \\
\text { SSTR4 } \\
\text { SSTR5 }\end{array}$ & $\begin{array}{l}\text { Secretory cells, basal cells, } \\
\text { smooth muscle stromal cells, } \\
\text { endothelial cells }\end{array}$ & $\begin{array}{l}\text { Normal, HGPIN } \\
\text { and incidental PCa }\end{array}$ \\
\hline Morichetti et al. [15] & 2009 & IHC & $\begin{array}{l}\text { SSTR1 } \\
\text { SSTR2 } \\
\text { SSTR3 } \\
\text { SSTR4 } \\
\text { SSTR5 }\end{array}$ & $\begin{array}{l}\text { Secretory cells, basal cells, } \\
\text { smooth muscle stromal cells, } \\
\text { endothelial cells }\end{array}$ & $\begin{array}{l}\text { PCa with NE } \\
\text { differentiation }\end{array}$ \\
\hline $\begin{array}{l}\text { Mazzucchelli et al. } \\
\text { (present study) }\end{array}$ & 2009 & IHC & $\begin{array}{l}\text { SSTR1 } \\
\text { SSTR2 } \\
\text { SSTR3 } \\
\text { SSTR4 } \\
\text { SSTR5 }\end{array}$ & $\begin{array}{l}\text { Secretory cells, basal cells, } \\
\text { smooth muscle stromal cells, } \\
\text { endothelial cells }\end{array}$ & $\begin{array}{l}\text { Complete androgen } \\
\text { ablated } \mathrm{PCa}\end{array}$ \\
\hline
\end{tabular}

Note: See text for abbreviations.

Nep, HGPIN and PCa from patients under CAA. This information could be of paramount importance in therapeutic approaches in which SST analogues could be combined with other drugs, including those that reduce the effect of androgens on PCa. However, further studies based on a double staining techniques are needed to correlate SSTR expression with other markers, including proliferation. This should help further interpret the relevance of SSTR expression in androgen ablated PCa.

\section{Acknowledgement}

This study was supported by a grant from Novartis Oncology, Italy. 
Table 9

Summary of the immunohistochemical expression and localization of somatostatin receptor subtypes in prostate cancer following complete androgen ablation

\begin{tabular}{|c|c|c|}
\hline Cell compartments & SSTR subtype expression & $\begin{array}{l}\text { Expression in the androgen ablation group } \\
\text { compared with the untreated group }\end{array}$ \\
\hline \multicolumn{3}{|l|}{ Secretory cells } \\
\hline - Membrane & - SSTR3 and 4 & - Mean percentages 30 (Nep) to $90 \%$ (HGPIN and PCa) lower \\
\hline • Cytoplasm & - All 5 SSTRs & $\begin{array}{l}\text { - No changes in Nep; mean percentages } \\
\text { lower for SSTR1, } 3 \text { and } 5 \text { ( } 30 \% \text { for SSTR1) }\end{array}$ \\
\hline - Nuclei & - SSTR4 and 5 & - No changes in Nep; 30-55\% lower in HGPIN and PCa \\
\hline \multicolumn{3}{|l|}{ Basal cells } \\
\hline - Membrane & - Not seen & - Not applicable \\
\hline - Cytoplasm & - All 5 SSTRs & - Mean percentages $10-40 \%$ lower \\
\hline - Nuclei & - Not seen & - Not applicable \\
\hline \multicolumn{3}{|c|}{ Smooth muscle and endothelial cells } \\
\hline - Membrane & - Not seen & - Not applicable \\
\hline - Cytoplasm & - All 5 SSTRs & - SSTR expression not affected \\
\hline - Nuclei & - Not seen & - Not applicable \\
\hline
\end{tabular}

\section{References}

[1] A.D. Balster, M.S. O’Dorisio, M.A. Summers and M.A. Turman, Segmental expression of somatostatin receptor subtypes sst(1) and sst(2) in tubules and glomeruli of human kidney, Am. J. Physiol. Renal. Physiol. 280 (2001), 457-465.

[2] C. Bousquet, J. Guillermet, F. Vernejoul, H. Lahlou, L. Buscail and C. Susini, Somatostatin receptors and regulation of cell proliferation, Dig. Liver Dis. 36 (2004), 2-7.

[3] P. Brazeau, W. Vale, R. Burgus, N. Ling, M. Butcher, J. Rivier and R. Guillemin, Hypothalamic polypeptide that inhibits the secretion of immunoreactive pituitary growth hormone, $\mathrm{Sci}$ ence 179 (1973), 77-79.

[4] A.E. Cariaga-Martinez, M.A. Lorenzati, M.A. Riera, M.A. Cubilla, A. De La Rossa, E.M. Giorgio, M.M. Tiscornia, E.M. Gimenez, M.E. Rojas, B.J. Chaneton, D.I. Rodríguez and P.D. Zapata, Tumoral prostate shows different expression pattern of somatostatin receptor 2 (SSTR2) and phosphotyrosine phosphatase SHP-1 (PTPN6) according to tumor progression, $A d v$. Urol. (2009) (Epub 2009 April 12).

[5] C. Casini Raggi, A. Calabro, D. Renzi, V. Briganti, F. Cianchi, L. Tesserini, R. Valanzano, M. Cameron Smith, C. Cortesini, F. Tonelli, M. Serio, M. Maggi and C. Orlando, Quantitative evaluation of somatostatin receptor subtype 2 expression in sporadic colorectal tumor and in the corresponding normal mucosa, Clin. Cancer Res. 8 (2002), 419-427.

[6] N. Dizeyi, L. Konrad, A. Bjartell, H. Wu, V. Gadaleanu, J. Hansson, L. Helboe and P.A. Abrahamsson, Localization and mRNA expression of somatostatin receptor subtypes in human prostatic tissue and prostate cancer cell lines, Urol. Oncol. 7 (2002), 91-98.

[7] G. Halmos, A.V. Schally, B. Sun, R. Davis, D.G. Bostwick and A. Plonowski, High expression of somatostatin receptors and messenger ribonucleic acid for its receptor subtypes in organconfined and locally advanced human prostate cancers, J. Clin. Endocrinol. Metab. 85 (2000), 2564-2571.
[8] J. Hansson, A. Bjartell, V. Gadaleanu, N. Dizeyi and P.A. Abrahamsson, Expression of somatostatin receptor subtypes 2 and 4 in human benign prostatic hyperplasia and prostatic cancer, Prostate 53 (2002), 50-59.

[9] C.A. Hornick, C.T. Anthony, S. Hughey, B.M. Gebhardt, G.D. Espenan and E.A. Woltering, Progressive nuclear translocation of somatostatin analogs, J. Nucl. Med. 41 (2000), 1256-1263.

[10] D.D. Klisovic, M.S. O’Dorisio, S.E. Katz, J.W. Sall, D. Balster, T.M. O'Dorisio, E. Craig and M. Lubow, Somatostatin receptor gene expression in human ocular tissues: RT-PCR and immunohistochemical study, Invest. Ophthalmol. Vis. Sci. 42 (2001), 2193-2201.

[11] U. Kumar, Expression of somatostatin receptor subtypes (SSTR1-5) in Alzheimer's disease brain: an immunohistochemical analysis, Neuroscience 134 (2005), 525-538.

[12] M. Mencoboni, S. Tredici, L. Rebella, M. Bergaglio, V. Galbusera, A. Manzara, F. Claudiani, B. Malcangi and M. Varaldo, Effect of chemotherapy on somatostatin receptor detection with octreotide scintigraphy in hormone-refractory prostate cancer patients, Anticancer Res. 26 (2006), 2233-2255.

[13] R. Montironi, L. Cheng, R. Mazzucchelli, D. Morichetti, D. Stramazzotti, A. Santinelli, G. Moroncini, A.B. Galosi, G. Muzzonigro, G. Comeri, J. Lovisolo, S. Cosciani-Cunico and A.V. Bono, Immunohistochemical detection and localization of somatostatin receptor subtypes in prostate tissue from patients with bladder outlet obstruction, Cell Oncol. 30 (2008), 473-482.

[14] R. Montironi, R. Mazzucchelli and T. van der Kwast, Morphological assessment of radical prostatectomy specimens. A protocol with clinical relevance, Virchows Arch. 442 (2003), 211217.

[15] D. Morichetti, R. Mazzucchelli, A. Santinelli, D. Stramazzotti, A. Lopez-Beltran, M. Scarpelli, A.V. Bono, L. Cheng and R. Montironi, Immunohistochemical expression and localization of somatostatin receptor subtypes in prostate cancer with neuroendocrine differentiation, IJPI (2010), to appear. 
[16] D. Morichetti, R. Mazzucchelli, D. Stramazzotti, A. Santinelli, A. Lopez-Beltran, M. Scarpelli, A.V. Bono, L. Cheng and R. Montironi, Immunohistochemical expression of somatostatin receptor subtypes in prostate tissue from cystoprostatectomies with incidental prostate cancer, BJU Int. (2010), to appear.

[17] Y.C. Patel, Somatostatin and its receptor family, Front Neuroendocrinol. 20 (1999), 157-198.

[18] M.G. Portela-Gomes, M. Stridsberg, L. Grimelius, K. Oberg and E.T. Janson, Expression of the five different somatostatin receptor subtypes in endocrine cells of the pancreas, Appl. Immunohistochem. Mol. Morphol. 8 (2000), 126-132.

[19] J.C. Reubi, B. Waser, J.C. Schaer and J.A. Laissue, Somatostatin receptor sst1-sst5 expression in normal and neoplastic human tissues using receptor autoradiography with subtypeselective ligands, Eur. J. Nucl. Med. 28 (2001), 836-846.

[20] J.C. Reubi, B. Waser, J.C. Schaer and R. Markwalder, Somatostatin receptors in human prostate and prostate cancer, J. Clin. Endocrinol. Metab. 80 (1995), 2806-2814.

[21] H. Reynaert, K. Rombouts, A. Vandermonde, D. Urbain, U. Kumar, P. Bioulac-Sage, M. Pinzani, J. Rosenbaum and
A. Geerts, Expression of somatostatin receptors in normal and cirrhotic human liver and in hepatocellular carcinoma, Gut $\mathbf{5 3}$ (2004), 1180-8119.

[22] G. Verset, C. Verslype, H. Reynaert, I. Borbath, P. Langlet, A. Vandebroek, M. Peeters, G. Houbiers, S. Francque, M. Arvanitakis and J.L. van Laethem, Efficacy of the combination of long-acting release octreotide and tamoxifen in patients with advanced hepatocellular carcinoma: a randomised multicentre phase III study, Br. J. Cancer 97 (2007), 582-588.

[23] M. Volante, M.P. Brizzi, A. Faggiano, S. La Rosa, I. Rapa, A. Ferrero, G. Mansueto, L. Righi, S. Garancini, C. Capella, G. De Rosa, L. Doglioni, A. Colao and M. Capotti, Somatostatin receptor type $2 \mathrm{~A}$ immunohistochemistry in neuroendocrine tumors: a proposal of a scoring system correlated with somatostatin receptor scintigraphy, Mod. Pathol. 20 (2007), 11721182.

[24] M.C. Zatelli and E.C. degli Uberti, Somatostatin receptors: from basic science to clinical approach - thyroid, Dig. Liver Dis. 36 (2004), 86-92. 


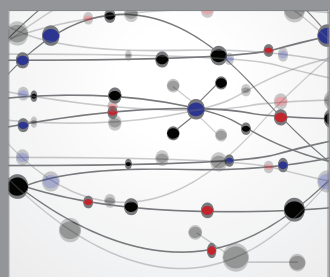

The Scientific World Journal
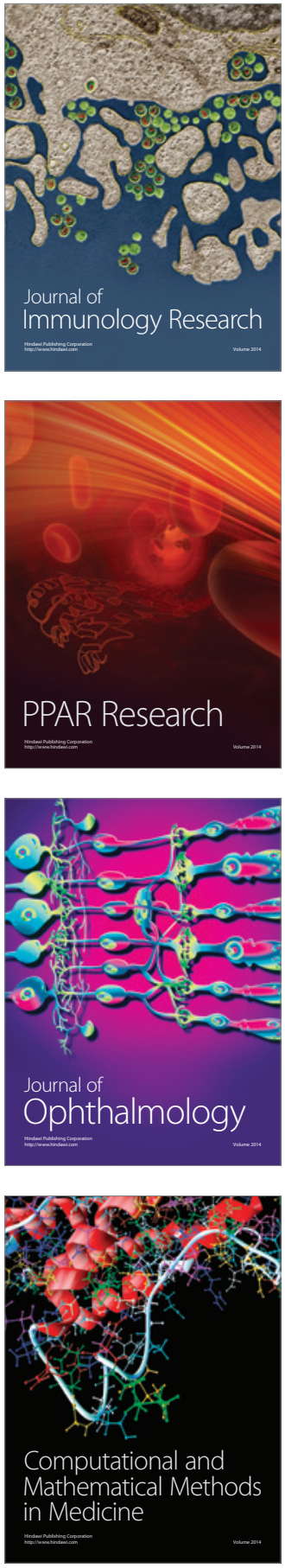

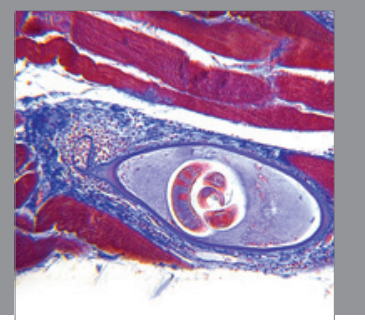

Gastroenterology

Research and Practice
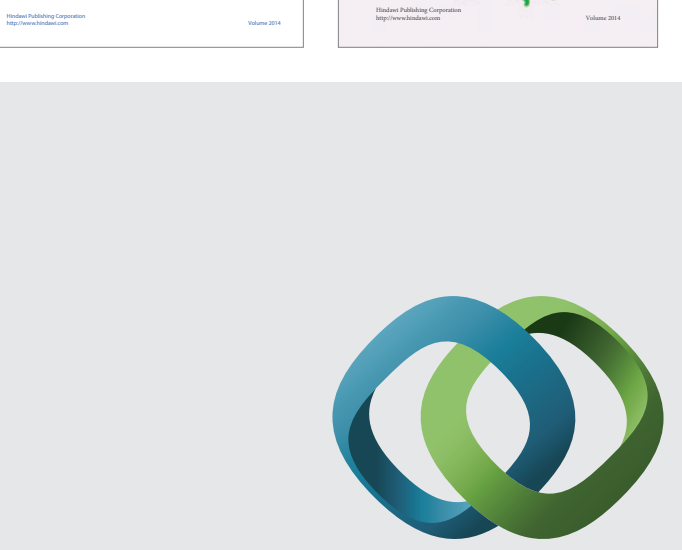

\section{Hindawi}

Submit your manuscripts at

http://www.hindawi.com
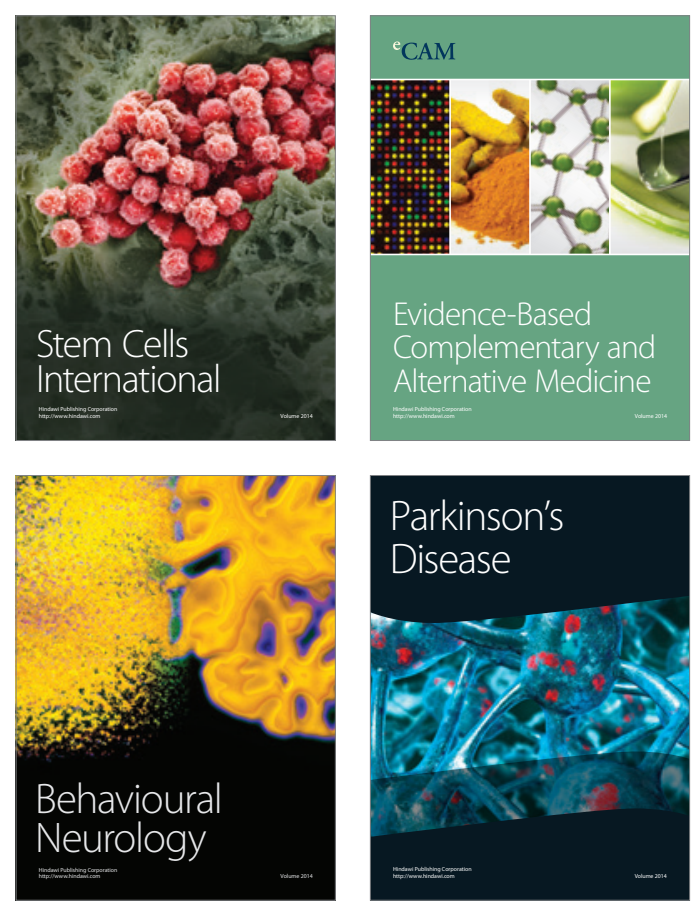

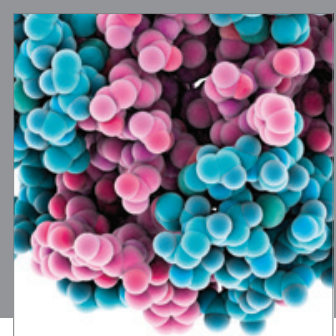

Journal of
Diabetes Research

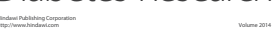

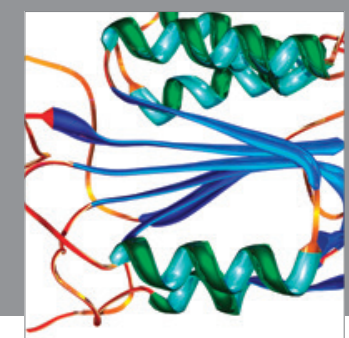

Disease Markers
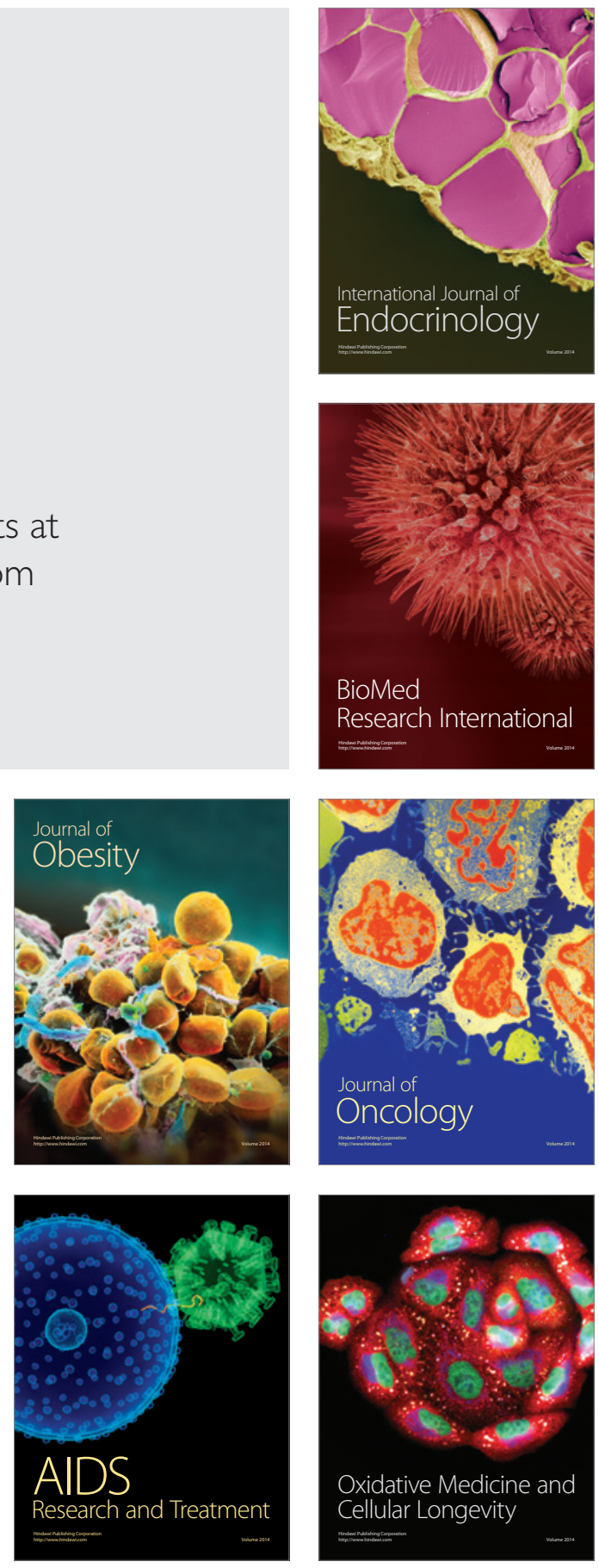